Journal of Thermal Engineering, Vol. 6, No. 5, pp. 736-750, October, 2020

Yildiz Technical University Press, Istanbul, Turkey

\title{
EXPERIMENTAL AND NUMERICAL INVESTIGATION OF CONTAMINANT CONTROL IN INTENSIVE CARE UNIT: A CASE STUDY OF RAIPUR, INDIA
}

\author{
Tikendra Nath Verma ${ }^{1 *}$, Shobha Lata Sinha ${ }^{2}$
}

\begin{abstract}
Proper ventilation is an important strategy in the practice of infection control. Hospitals are complex atmospheres that require ventilation for thermal comfort of patients as well as control of harmful pathogens infection emissions. The present study is performed on a hospital at Raipur $\left(21.2514^{\circ} \mathrm{N}, 81.6296^{\circ} \mathrm{E}\right)$, India, to analyze the avoidance of airborne infections from the mouth of patient to protect the doctor and other patients in the intensive care unit (ICU) using Computational Fluid Dynamics (CFD) software FLUENT. Incense smoke is used to for capturing velocity field. Twenty seven (27) cases of simulation were executed using different air change per hour (ACH) $(6,9$ $\& 12)$ and different inlet and outlet positions talking into account the constant inlet temperature $\left(20^{\circ} \mathrm{C}\right)$. The wall temperatures were taken out from ISHRAE handbook for Raipur region. The velocity vector and capturing the flow field were also performed experimentally. All three turbulence model (Standard, RNG \& Realizable) predictions have shown to be in good agreement with the experimental data. It can be effectively employed to validate the extensively used k- $\varepsilon$ model which was commonly used for ICU.
\end{abstract}

Keywords: CFD, Ventilation Design, Simulation, Airborne Disease

\section{INTRODUCTION}

The dispersion of air borne disease can be impeded if infected patients are segregated from those who are not infected. The effectiveness of proper ventilation and contaminant control analysis has not been performed well till date. The quality of air in hospital environments is of specific concern as patients may serve as a source of pathogenic bacteria to staff and hospital people. Bacteria, virus and other air borne microorganisms which are harmful to living beings are easily spread through the air we inhale from the surroundings. A hospital is an institution for treatment of various diseases caused by many organisms. Even at an institution for treatment, diseases are still spread through improper handling and maintenance of infected area or beings. One such method of infection transfer in hospitals is the spread of the pathogen through air. Computational fluid dynamics (CFD) is used as an effective tool for studying various real time problems which are expensive and difficult to solve experimentally. An important application includes the use of commercial CFD software in solving fluid flow patterns with variable parameters such as boundary conditions and ventilation strategies. CFD using Eulerian and Lagangian methods have the ability to predict the steady state particle concentration distribution. Various case studies using CFD for fluid flow in ventilations of multiple/single bed hospitals were performed. Particulate dispersion in hospitals equipped with heating, ventilation and air conditioning (HVAC) and variable air volume (VAV) systems were also considered. The effect of the location of the infected patients in transmitting air borne diseases with hospital using CFD is also presented. [1-10].

The effect of ventilation, flow differential and passage on the air flow patterns across an isolated room was studied and the generation of greater flow in the hinged door than the sliding door through baseline smoke patterns was studied. Tracer gas with various ventilation rates of 6 and 12 air change per hour (ACH) had a less impact on the exchange of air across the hinged door. They have concluded that the sliding door model in isolated rooms of a hospital have better effectiveness in reducing air volume exchange during opening of door [11]. The cross-infection risks of air borne diseases are reported to have been reduced through higher rate of ventilation in hospitals. It was reported that natural ventilation has more effectiveness than mechanical ventilation in-terms of higher ventilation rate and energy efficiency through opening both doors and windows in a ward, with highest ventilation rate obtained in $69.0 \mathrm{ACH}$

This paper was recommended for publication in revised form by Regional Editor Mohammad Rahimi-Gorji

${ }_{1}$ Department of Mechanical Engineering, Maulana Azad National Institute of Technology Bhopal, India

${ }^{2}$ Department of Mechanical Engineering, National Institute of Technology Raipur, India.

*E-mail address: layth.ismael@ozu.edu.tr, 130006@uotechnology.edu.iq

Orcid id: 0000-0002-3884-8758

Manuscript Received 22 October 2018, Accepted 24 December 2018 
[12]. Another study reported the spread of severe acute respiratory syndrome (SARS) and H1N1 virus through coughing and speaking. Though the study was conducted with use of particle image velocimetry (PIV), the results have yield that the average initial coughing velocity was $15.3 \mathrm{~m} / \mathrm{s}$ (male) and $10.6 \mathrm{~m} / \mathrm{s}$ (female). The average initial speaking velocity was $4.07 \mathrm{~m} / \mathrm{s}$ and $2.31 \mathrm{~m} / \mathrm{s}$ for male and female respectively [13]. Tracer gas is used effectively in studying the fluid flow and air borne pathogen transmission in a six-bedded isolated room through walking motion of health care workers (HCW). RNG k- $\varepsilon$ model is used to validate the results. Conditions like HCW walking with arms $\&$ legs swinging are taken as mixing process. The study have resulted that flow disturbance after stopping the motion of $\mathrm{HCW}$ (5.4 s to $25.4 \mathrm{~s}$ ) have larger impact in spreading the gases, thereby requiring more than 30-60 s for the flow to recover in its initial position even after the motion of $\mathrm{HCW}$ is stopped. $6 \mathrm{ACH}$ is reported to have more spreading of gases than $12.9 \mathrm{ACH}[14]$.

To accurately define boundary conditions like contaminants source, distribution and mixing with supply air in CFD, series of transient distribution of contaminants is developed through transient accessibility indices and analytical expressions. Experimental analysis is performed to validate the accuracy of the analytical expressions [15]. The contaminant control in a minienvironment through particle concentration measurement using CFD is performed through which particle concentrations and transfer route of contaminants were measured. They have proposed the concept of improving the yield and energy consumption of the system [16]. The control of air flow through rearrangement of air return by regulation from the ward cubicle using CFD on a general ward ventilation design was performed by researcher in a study. It assures the removal of microbes effectively at lower cost, minimizing cross infection [17]. The location of outlet in a single ceiling air diffuser plays an important role in the desired occupied zones. Adoption of variable inclination angles at inlet is recommended for improving air distribution profiles on applications like medical clean room [18]. The importance of error evaluation for solving air flow \& heat transfer around human health body problems using CFD were discussed [19]. An additional study also revealed that the respiratory events such as breathing, sneezing, talking and coughing were the main source of transfer of contaminants. The study uses a model of equations using various parameters like rate of flow, area of mouth orifice opening etc, and proposed that the model be used for describing source of contaminant transfer due to talking and breathing [20]. SIMPLE and SIMPLEC algorithms for steady, laminar and incompressible flow under Boussineq's approximation for various positions of inlet and outlet in a room heated with warm air is used with variable Grashof and Reynolds number. It was concluded that locating the outlet at a higher position than inlet led to enhanced temperature distribution [21]. The air flow patterns of an operating room (OR) during opening and foot traffic are studied. Even though OR have slightly higher pressure than other adjacent rooms, a small volume of air still enters during a cycle of door opening and closing even without any person entering the room. The study have revealed higher volume of air enters the OR if the person enters the OR [22].

The evaporation and condensation of expiration droplets and their size (coughing and speaking) have been found to have negligible impact on usual droplet size from human beings $(13.5 \mu \mathrm{m}$ from coughing and $16.0 \mu \mathrm{m}$ from speaking) for average expiration velocity of $11.7 \mathrm{~m} / \mathrm{s}$ and $3.9 \mathrm{~m} / \mathrm{s}$ for coughing and speaking respectively [23]. Contaminant distribution in an office environment of $6.6 \mathrm{~m}(\mathrm{~L}) \times 3.7 \mathrm{~m}(\mathrm{~W}) \times 2.6 \mathrm{~m}(\mathrm{H})$ dimension with air conditioning and mechanical ventilation was also studied. Tracer gas (SF6) is used for simulation of contaminants on a model room and CFD was used for validating the results. The study revealed that the pattern of contaminant dispersion depends greatly on the velocity flow field. The layout of various objects like furniture also influences the pattern of air flow and contaminant. Other study suggests that CFD can be used effectively in predicting the spatial distribution of bio-aerosol in indoor environments like hospitals. The study was conducted at three different layoutsempty, single bed and two bed rooms. Deposition of the particles have no correlation with relative surface concentration and source distance but partition among the patients proved to be effective in reducing cross contamination among patients. [24, 25]. Other areas in using CFD for numerical study of fluid flow and particle trajectory includes one bed hospital, particle motion in ICU, air pollution in hospital modelling, ventilation of hospital rooms, deposition of particle and air flow in IC Engines, nano-fluid study, fluid flow and pressure distribution in bearings etc. [31- 44]. While CFD is an effective tool for numerical study, other numerical study involving ANN may be conducted for enhancing the results, as studies reported earlier have confirmed the same [45-54]. 
The above authors have performed various experiments in different regions using the respective environment conditions. The authors in this paper have performed real time study through the application of both experimental and numerical methods on the environment conditions of the hospital in Raipur $\left(21.2514^{\circ} \mathrm{N}, 81.6296^{\circ} \mathrm{E}, 298 \mathrm{~m}\right.$ altitude above sea level),Chhattisgarh, India taking into consideration the wall temperature from ISHRAE handbook (2007) for Raipur [26].

\section{THEORY PROBLEM STATEMENT}

In the present study, numerical simulation of ICU room for single-patient has been carried out. Total nine (9) different positions of inlet and outlet for three (3) different Reynolds numbers have been considered. The overall dimension of ICU room has been considered as $4 \mathrm{~m}$ (width) $\times 3 \mathrm{~m}$ (Height) $\times 6 \mathrm{~m}$ (length). The room consists of a patient (source of contaminant), doctor, bed, light, stool and oxygen cylinder. In all the twenty seven (27) cases, as provided in table. 1 , the level of the inlet position is constant i.e. $2.3 \mathrm{~m}$ above the floor. The outlet is situated $1.7 \mathrm{~m}$ in front of the east wall. The distances of the outlet from the floor are considered to be $0.3 \mathrm{~m}, 1.4 \mathrm{~m}, 2.3 \mathrm{~m}$ and the distances of the inlet from west wall are $2.8 \mathrm{~m}, 1.7 \mathrm{~m}, 0.6 \mathrm{~m}$ respectively, as shown in figure 1 .
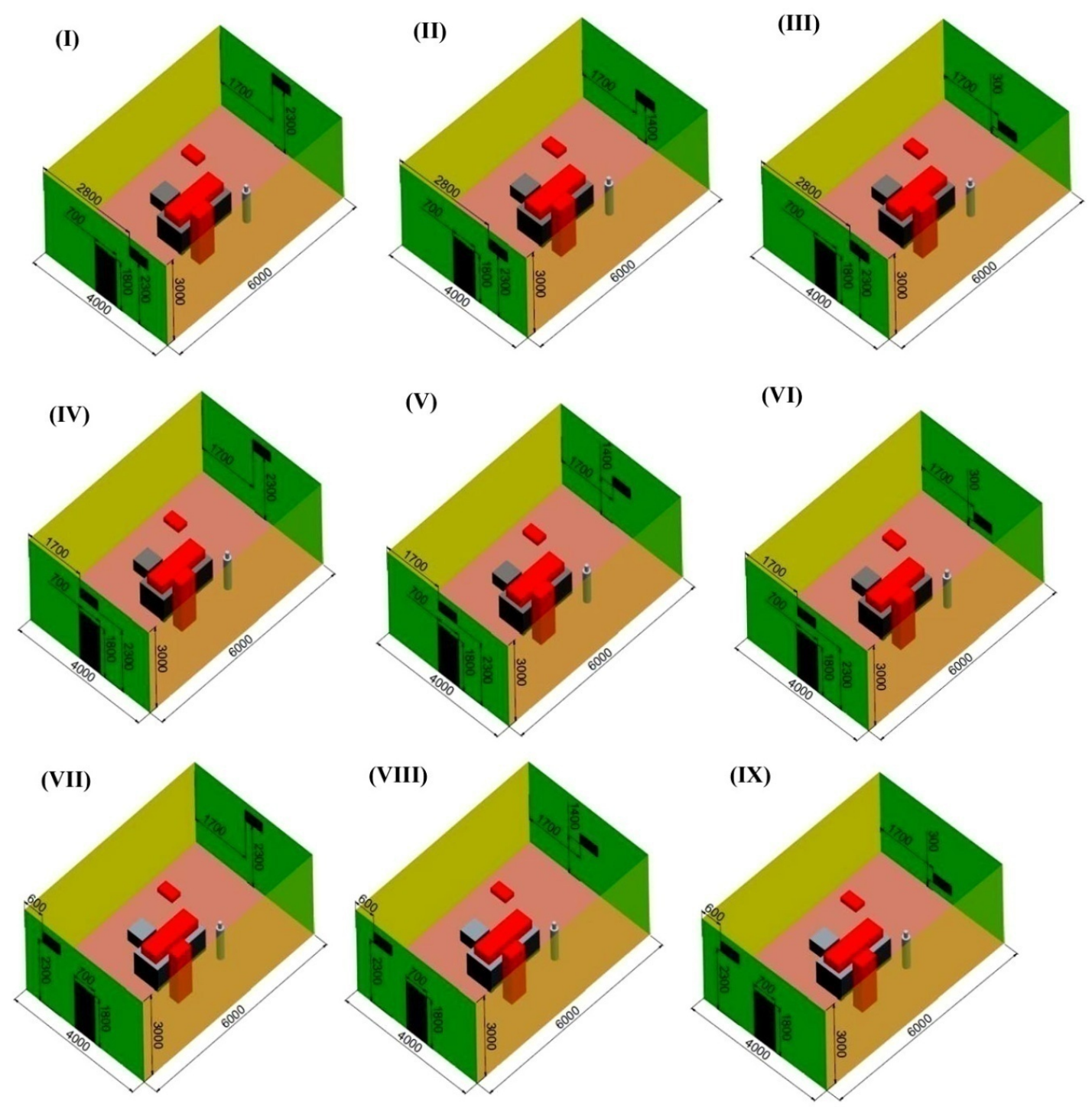

Figure 1. Computational domain of various inlet and outlet positions of ICU with different cases 
Journal of Thermal Engineering, Research Article, Vol. 6, No. 5, pp.736-750, October, 2020

Table 1. Details of computational model of various configurations (cases)

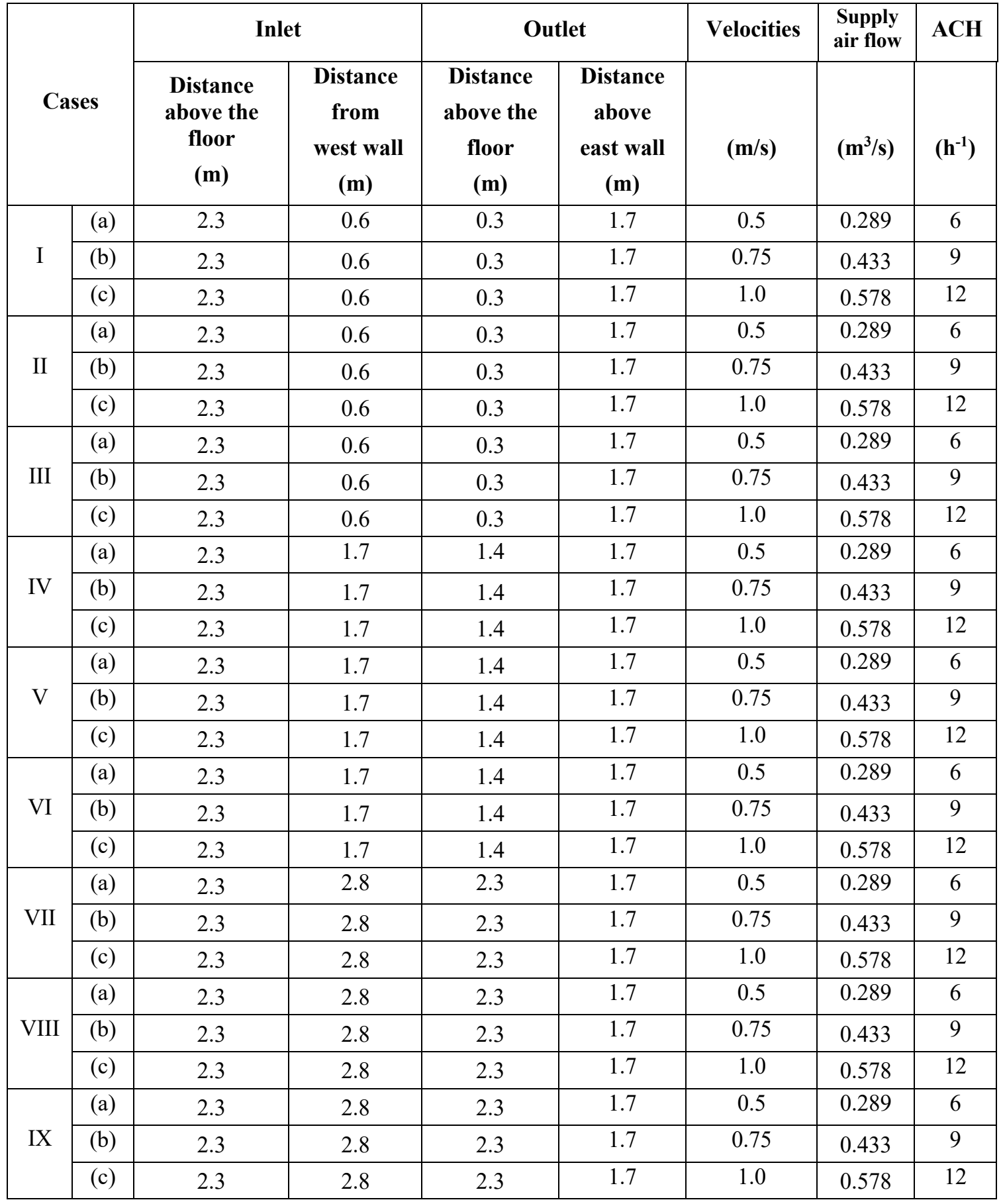

\section{Computational fluid dynamics}

The CFD models are used to predict the air velocity, turbulence level, particle tracking, pressure and temperature of the computational models. In the present work, the $k-\varepsilon$ model (Standard, RNG \& Realizable) is used for all numerical simulation process. The corresponding equations are given in equation $(1-6)$ in which equation (1) $\&$ (2) are for Standard $k$ - $\varepsilon$ model, equation (3) \& (4) are for RNG $k$ - $\varepsilon$ model and equation (5) \& (6) are for Realizable $k$ - $\varepsilon$ model. The models constant for turbulence is tabulated in table.2. The obstruction for flow field which were present 
and considered during the study is given in table.3. The boundary conditions for the used $k-\varepsilon$ model are given in table 4.

$$
\begin{gathered}
\frac{\partial}{\partial t}(\rho k)+\frac{\partial}{\partial x_{i}}\left(\rho k u_{i}\right)=\frac{\partial}{\partial x_{j}}\left[\left(\mu+\frac{\mu_{t}}{\sigma_{k}}\right) \frac{\partial k}{\partial x_{j}}\right]+G_{k}+G_{b}-\rho \varepsilon-Y_{M}+S_{K} \\
\frac{\partial}{\partial t}(\rho \varepsilon)+\frac{\partial}{\partial x_{i}}\left(\rho \varepsilon u_{i}\right)=\frac{\partial}{\partial x_{j}}\left[\left(\mu+\frac{\mu_{t}}{\sigma_{\varepsilon}}\right) \frac{\partial \varepsilon}{\partial x_{j}}\right]+C_{1 \varepsilon} \frac{\varepsilon}{k}\left(G_{k}+C_{3 \varepsilon} G_{b}\right)-C_{2 \varepsilon} \rho \frac{\varepsilon^{2}}{k}+S_{\varepsilon} \\
\frac{\partial}{\partial \mathrm{t}}(\rho \mathrm{k})+\frac{\partial}{\partial \mathrm{x}_{\mathrm{i}}}\left(\rho \mathrm{ku}_{\mathrm{i}}\right)=\frac{\partial}{\partial \mathrm{x}_{\mathrm{j}}}\left(\alpha_{\mathrm{k}} \mu_{\mathrm{eff}} \frac{\partial \mathrm{k}}{\partial \mathrm{x}_{\mathrm{j}}}\right)+\mathrm{G}_{\mathrm{k}}+\mathrm{G}_{\mathrm{b}}-\rho \varepsilon-\mathrm{Y}_{\mathrm{M}}+\mathrm{S}_{\mathrm{k}} \\
\frac{\partial}{\partial \mathrm{t}}(\rho \varepsilon)+\frac{\partial}{\partial \mathrm{x}_{\mathrm{i}}}\left(\rho \varepsilon \mathrm{u}_{\mathrm{i}}\right)=\frac{\partial}{\partial \mathrm{x}_{\mathrm{j}}}\left(\alpha_{\varepsilon} \mu_{\mathrm{eff}} \frac{\partial \varepsilon}{\partial \mathrm{x}_{\mathrm{j}}}\right)+\mathrm{C}_{1 \varepsilon} \frac{\varepsilon}{\mathrm{k}}\left(\mathrm{G}_{\mathrm{k}}+\mathrm{C}_{3 \varepsilon} \mathrm{G}_{\mathrm{b}}\right)-\mathrm{C}_{2 \varepsilon} \rho \frac{\varepsilon^{2}}{\mathrm{k}}\left(\mathrm{G}_{\mathrm{k}}+\mathrm{C}_{3 \varepsilon} \mathrm{G}_{\mathrm{b}}\right)- \\
\frac{\partial}{\partial t}(\rho k)+\frac{\partial}{\partial x_{j}}\left(\rho k u_{j}\right)=\frac{\partial}{\partial x_{j}}\left[\left(\mu+\frac{\mu_{t}}{\sigma_{k}}\right) \frac{\partial k}{\partial x_{j}}\right]+\mathrm{R}_{k}+G_{b}-\rho \varepsilon-Y_{M}+S_{k} \\
\frac{\partial}{\partial t}(\rho k)+\frac{\partial}{\partial x_{j}}\left(\rho \varepsilon u_{j}\right)=\frac{\partial}{\partial x_{j}}\left[\left(\mu+\frac{\mu_{t}}{\sigma_{\varepsilon}}\right) \frac{\partial \varepsilon}{\partial x_{j}}\right]+\rho C_{1} S_{\varepsilon}-\rho C_{2} S_{\varepsilon}-\rho C_{2} \frac{\varepsilon^{2}}{k+\sqrt{v \varepsilon}}+ \\
C_{1 \varepsilon} \frac{\varepsilon}{k} C_{3 \varepsilon} G_{b}+S_{\varepsilon}
\end{gathered}
$$

The following are the assumptions made during the numerical modeling and simulations. Heat and mass transfer between air and contaminated particles trajectory are neglected. The walls, floor and ceiling of the room are

\begin{tabular}{|c|c|c|c|c|c|c|c|c|c|c|c|}
\hline Parameter & $u(\mathrm{~m} / \mathrm{s})$ & $v(\mathrm{~m} / \mathbf{s})$ & $w(\mathbf{m} / \mathbf{s})$ & $K\left(\mathrm{~m}^{2} / \mathbf{s}^{2}\right)$ & $\varepsilon\left(\mathbf{m}^{2} / \mathbf{s}^{3}\right)$ & Conditions & \multicolumn{5}{|c|}{ Temperature $\left({ }^{\circ} \mathrm{C}\right)$} \\
\hline At the inlet & $\begin{array}{c}0.5,0.75 \\
1.0\end{array}$ & 0 & 0 & 0.005 & $\frac{k^{1.5}}{w}$ & $\begin{array}{l}\text { velocity } \\
\text { inlet }\end{array}$ & \multicolumn{5}{|c|}{20} \\
\hline $\begin{array}{l}\text { At the } \\
\text { outlet }\end{array}$ & 0 & 0 & 0 & 0 & 0 & outflow & \multicolumn{5}{|c|}{--} \\
\hline \multirow{2}{*}{ At the wall } & \multirow{2}{*}{0} & \multirow{2}{*}{0} & \multirow{2}{*}{0} & \multirow{2}{*}{0} & \multirow{2}{*}{0} & \multirow{2}{*}{$\begin{array}{l}\text { no slip } \\
\text { conditions }\end{array}$} & E & $\mathrm{W}$ & $\mathrm{N}$ & $\mathrm{S}$ & $\mathrm{C}$ \\
\hline & & & & & & & 31 & 25 & 17 & 28 & 48 \\
\hline
\end{tabular}
considered to be well insulated. No particle rebounds on solid surfaces, such as walls, floors and ceilings have been considered.

Table 2. Turbulence model constant

\begin{tabular}{|l|l|l|l|l|l|}
\hline $\boldsymbol{k}$ - $\boldsymbol{\varepsilon}$ Model & $\mathbf{C}_{\boldsymbol{\mu}}$ & $\mathbf{C}_{\mathbf{1} \boldsymbol{\varepsilon}}$ & $\mathbf{C}_{\mathbf{2} \boldsymbol{\varepsilon}}$ & $\boldsymbol{\sigma}_{\mathbf{k}}$ & $\boldsymbol{\sigma}_{\boldsymbol{\varepsilon}}$ \\
\hline Standard & 0.09 & 1.44 & 1.92 & 1 & 1.3 \\
\hline $\begin{array}{l}\text { Renormalization } \\
\text { (RNG) }\end{array}$ & - & 1.42 & 1.68 & - & - \\
\hline Realizable & - & 1.44 & 1.9 & 1 & 1.2 \\
\hline
\end{tabular}

Table 3. Objects in the ICU

\begin{tabular}{|l|l|l|}
\hline S.No. & Occupancy & Dimensions $(\mathbf{m})$ \\
\hline 1. & Doctor & $0.3 \times 1.7 \times 0.5$ \\
\hline 2. & Patient & $0.3 \times 1.5 \times 0.5$ \\
\hline 3. & Bed & $0.8 \times 0.8 \times 1.7$ \\
\hline 4. & Stool & $0.5 \times 0.5 \times 0.4$ \\
\hline 5. & Door & $0.7 \times 1.8$ \\
\hline
\end{tabular}

Table 4. Boundary conditions 


\section{Grid independence test $\& \mathrm{Y}^{+}$value}

FLUENT software is used to perform the steady state numerical solutions. Tetrahedral elements with an unstructured mesh have been used to discretize the computational domain of ICU. Different grid sizes $\left(5.5 \times 10^{6}\right.$ and $10 \times 10^{6}$ cells) were used for grid independence test (GIT). The maximum gradients of transport parameters such as air (outlet, inlet), near humans (patient and doctors) were chosen for mesh refinement to obtain flow and heat transfer characteristics. The computational domain in the inner, outer and center zone has been kept in the range of $1 \leq \mathrm{Y}^{+} \leq 7$. The study uses various cell sizes $(0.035 \mathrm{~m}, 0.05 \mathrm{~m}$ and $0.08 \mathrm{~m})$

\section{Particle trajectory}

The following equation (7) is used for calculation of the discrete phase particle trajectory.

$$
\frac{d u_{p}}{d t}=F_{D}\left(u_{i}-u_{p}\right)+\frac{g\left(\rho_{p}-\rho\right)}{\rho_{p}}+F_{x}
$$

where $F_{D}\left(u_{i}-u_{p}\right)$ is drag force per unit particle mass, $\frac{g\left(\rho_{p}-\rho\right)}{\rho_{p}}$ is gravitational force per unit particle mass $\left(\mathrm{m} / \mathrm{s}^{2}\right), \mathrm{F}_{\mathrm{x}}$ is additional force exerted on the particles.

Some forces are negligible as they were generally small. The $\mathrm{F}_{\mathrm{D}}$ is defined by using the Stokes law (equation (8).

$$
F_{D}=\frac{18 \mu}{\rho_{p} d_{p}^{2}} \frac{C_{d} \operatorname{Re}}{24}
$$

Where $\operatorname{Re}$ and $\mathrm{C}_{\mathrm{d}}$ are defined by the equations (9) and (10) respectively.

$$
\begin{aligned}
R e & =\frac{\rho d_{p}\left|u_{p}-u\right|}{\mu} \\
C_{d} & =a_{1}+\frac{a_{2}}{R e}+\frac{a_{3}}{R e^{2}}
\end{aligned}
$$

During the computation, all contaminated particles are assumed to be of spherical solid shape, heat and mass transfer between air and contaminated particles are neglected and no particle rebounds on solid surfaces (walls, floors and ceilings). The Coefficient of drag $\left(C_{D}\right)$ from equation (8) was calculated [27] which regulates the value of $C_{D}$ for the particle (spherical) over a extensive range of Reynolds number. The particles have no control on the gas [28]. The above assumptions were validated through checking during the post processing of the results [4].

$$
d_{p} \leq \frac{1.33 v}{Z . \sigma}
$$

Where $Z$ is the ratio of particle mass flow rate to gas mass flow rate, $\sigma$ is standard deviation of the particles fluctuating velocity [5]

The particle deposition effects were neglected since the deposition velocity and coefficient of loss deposition were low [29].

\section{RESULTS AND DISCUSSION}

The result is presented in both numerical model and experimentation work. The contaminant control in the various twenty-seven different models was presented herein the numerical solutions.

\section{Contaminant particle movement}

The movement of contaminants in a hospital is complex and difficult to predict. Different types of contaminants react different flow paths at different velocities. Every contaminant has a unique set chemical properties and physical properties. 

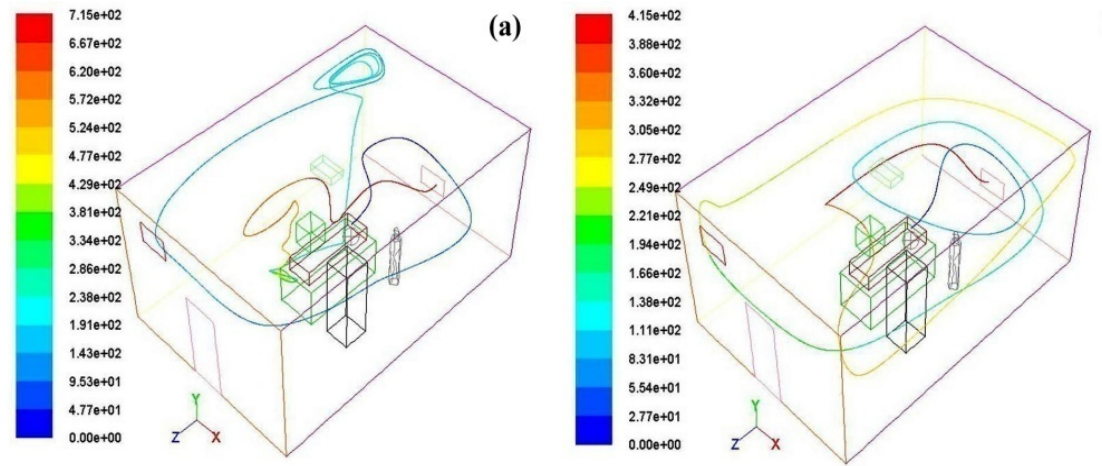

(b)

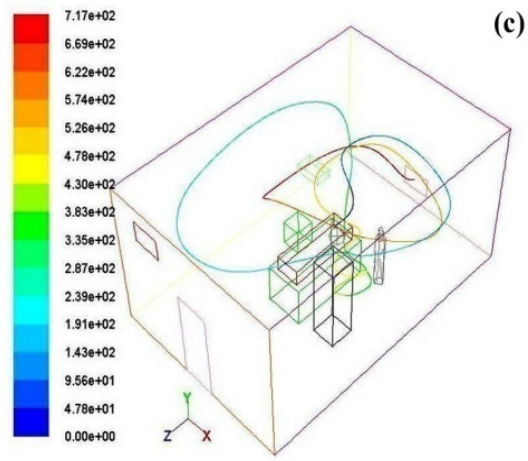

Figure 2. Particle movement of case-I
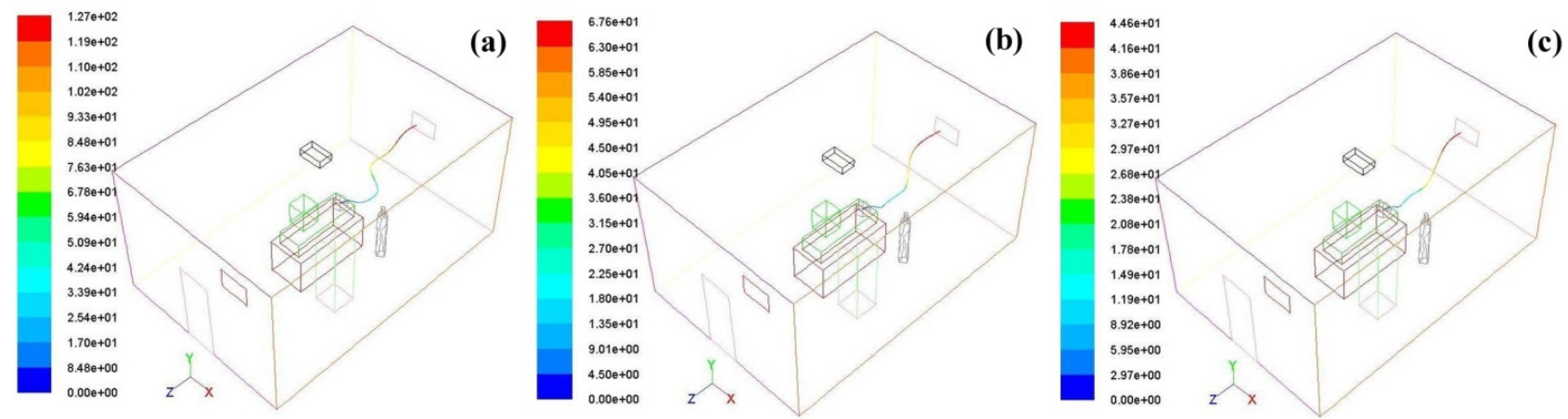

Figure 3. Particle movement of case-II
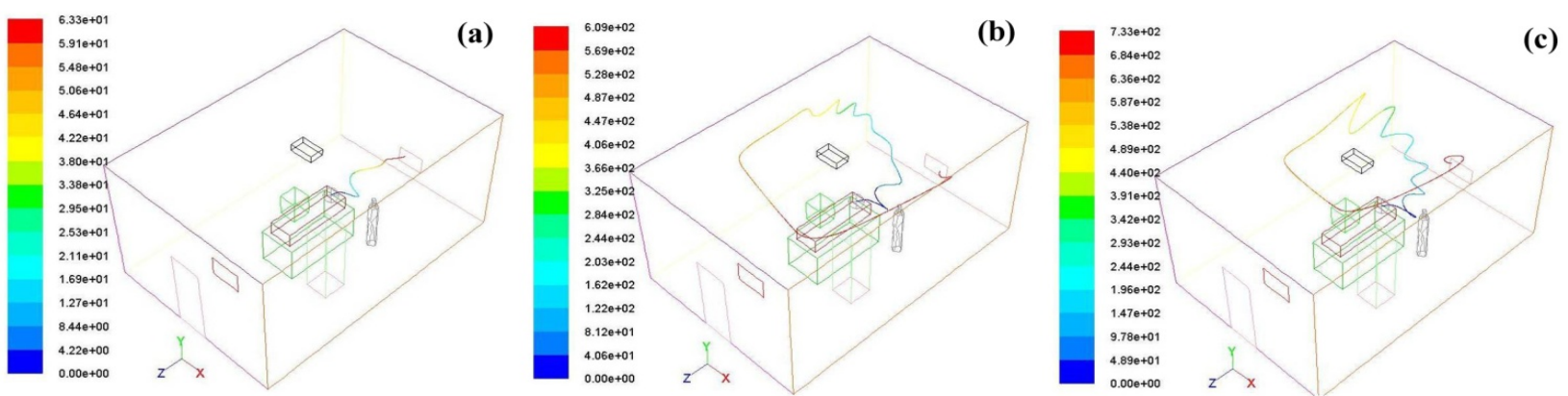

Figure 4. Particle movement of case-III
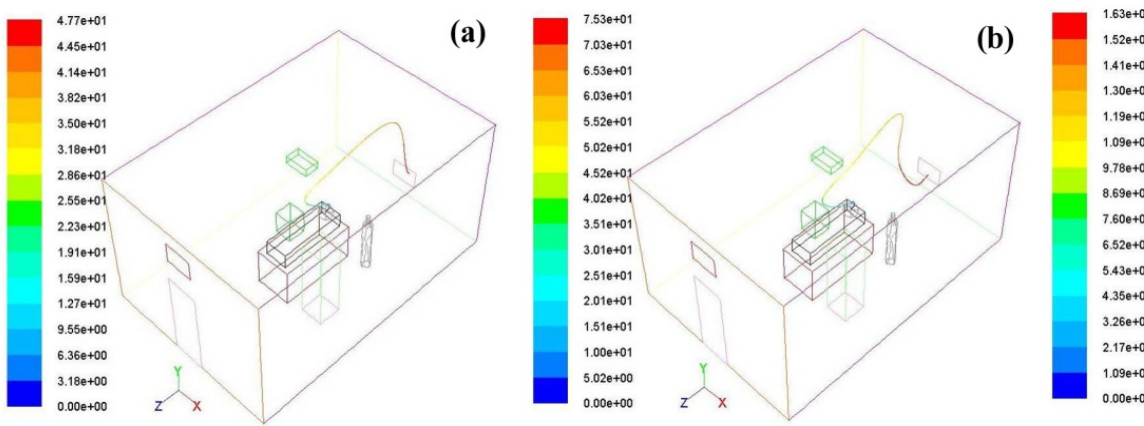

(c)

Figure 5. Particle movement of case-IV 

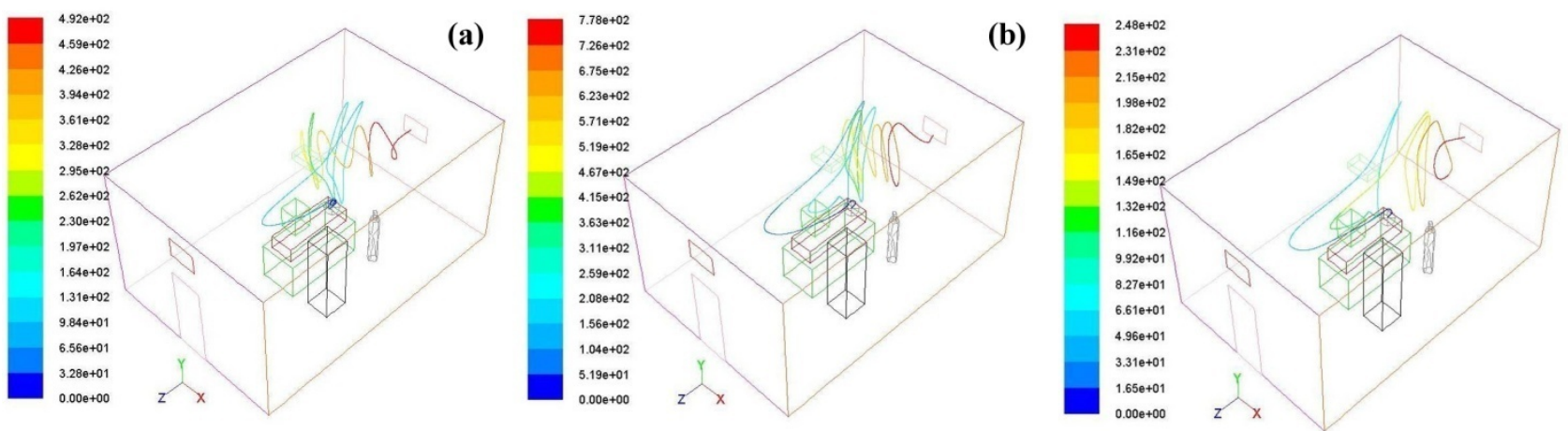

(c)

Figure 6. Particle movement of case-V
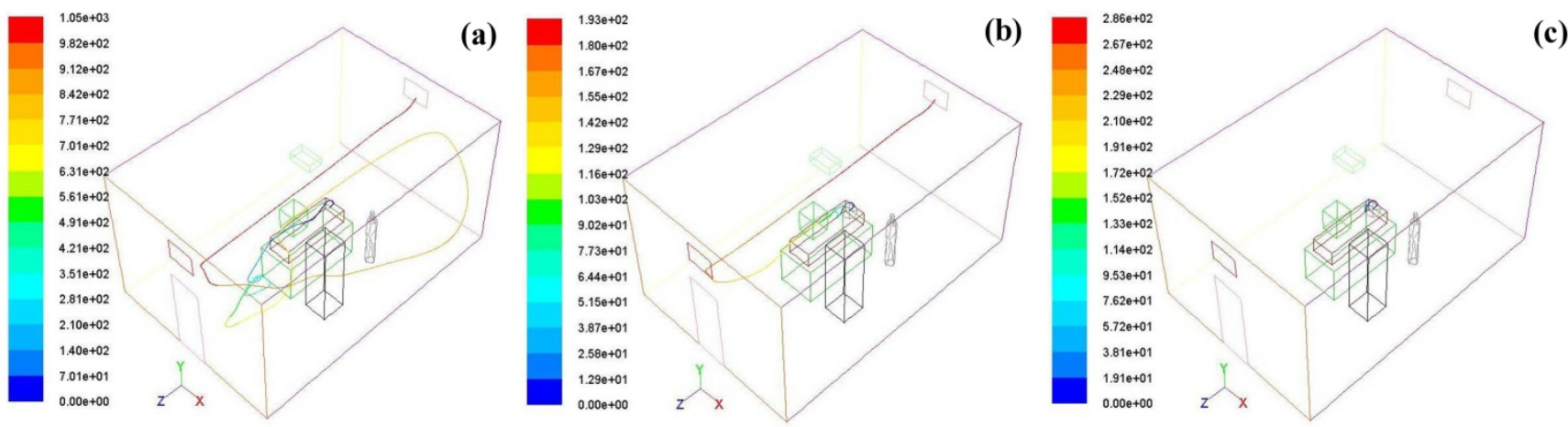

Figure 7. Particle movement of case-VI
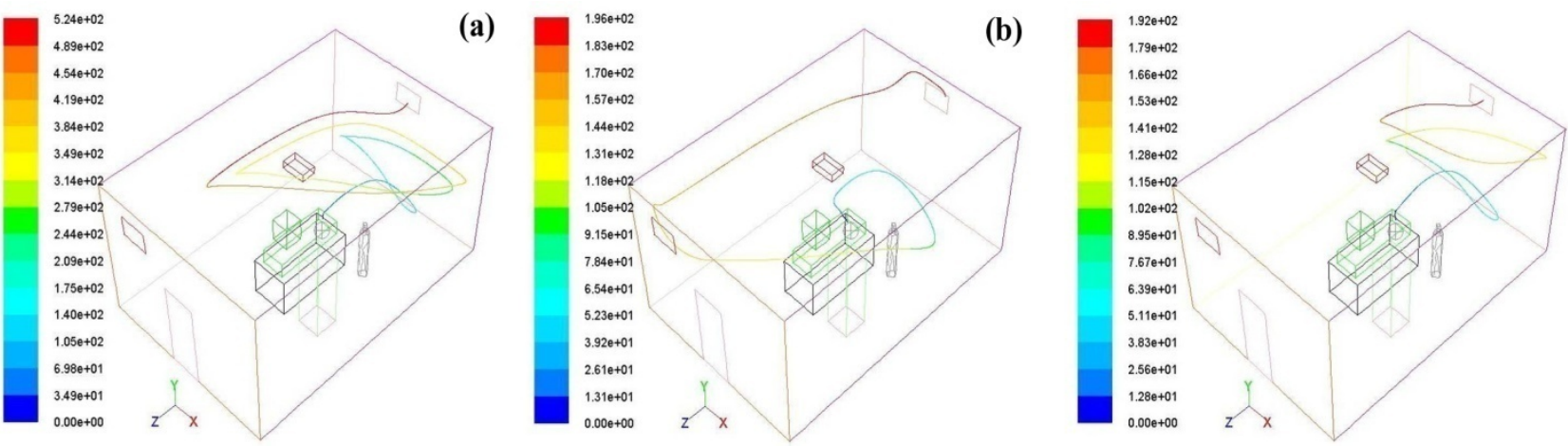

(c)

Figure 8. Particle movement of case-VII
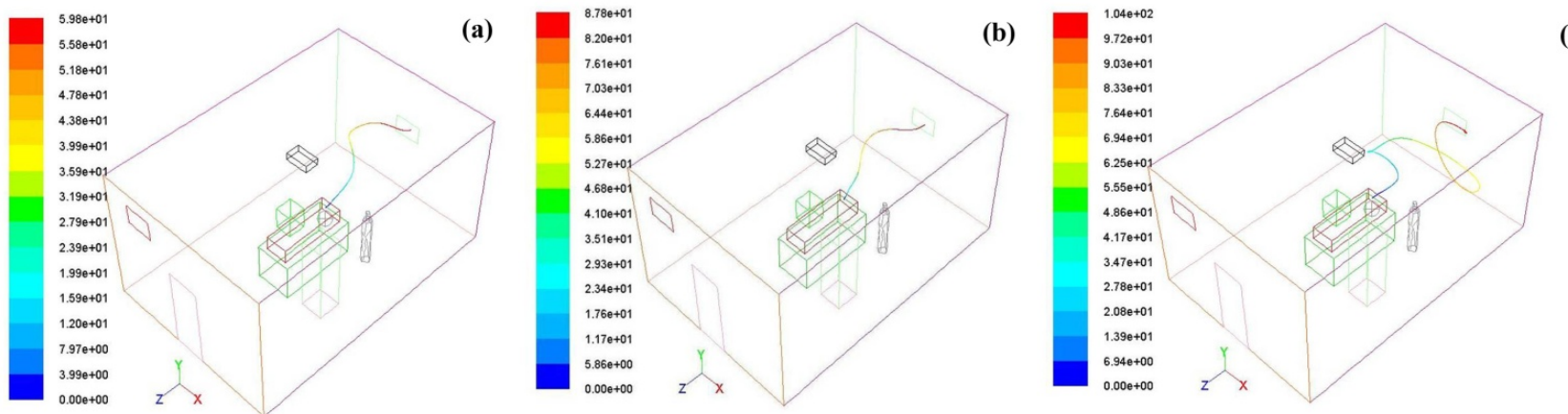

(c)

Figure 9. Particle movement of case-VIII 

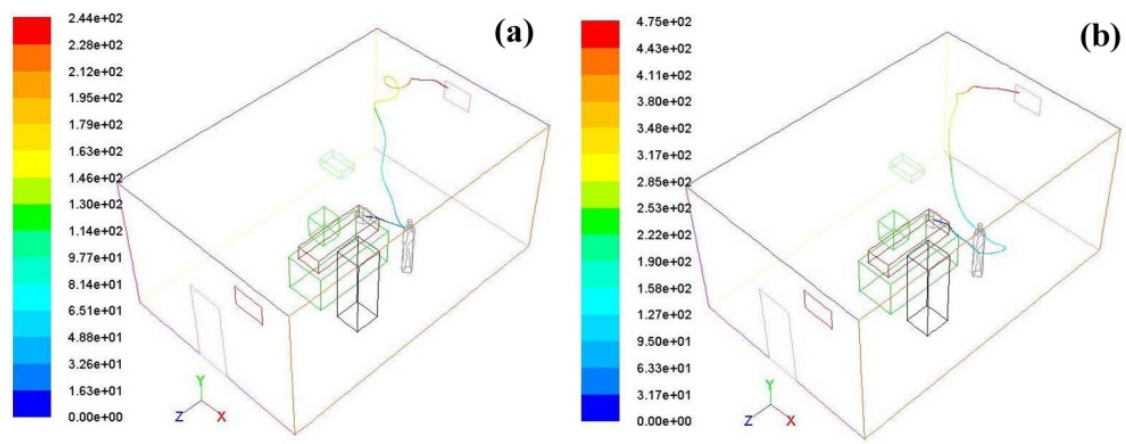

(b)

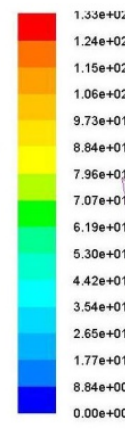

(c)

Figure 10. Particle movement of case-IX

Figure 2 to $10[(\mathrm{a}),(\mathrm{b}),(\mathrm{c})]$ shows the movement of mass less contaminated particle coming from the mouth of patient when velocities are $0.5 \mathrm{~m} / \mathrm{s}, 0.75 \mathrm{~m} / \mathrm{s}$ and $1.0 \mathrm{~m} / \mathrm{s}$ respectively. The contaminated particle starts from the mouth of patient, moves through tortuous path and leaves through the outlet without affecting the doctor or patient. The total time taken by the mass less contaminated particle to leave the ICU is tabulated in the table 5. Path of mass less particle is more/less tortuous and varying from case to case. In case VI- (c), from figure 7, the contaminated particle is not leaving the room and it is settling in the ICU. Thus, it is affecting the health of the patient and other people.

Table 5. Time of contaminant leaving from ICU (seconds)

\begin{tabular}{|c|c|c|c|}
\hline Cases & $\begin{array}{l}\text { Velocity } \\
(\mathbf{m} / \mathbf{s})\end{array}$ & $\begin{array}{c}\text { Time required } \\
\left(T_{r}\right) \\
\text { (seconds) }\end{array}$ & $\begin{array}{c}\text { Maximum time } \\
\left.\text { ( } T_{\max }\right) \\
\text { (seconds) }\end{array}$ \\
\hline \multirow{3}{*}{ I } & 0.5 & 715 & \multirow{3}{*}{715} \\
\hline & 0.75 & 415 & \\
\hline & 1.0 & 715 & \\
\hline \multirow{3}{*}{ II } & 0.5 & 127 & \multirow{3}{*}{127} \\
\hline & 0.75 & 6.76 & \\
\hline & 1.0 & 4.46 & \\
\hline \multirow{3}{*}{ III } & 0.5 & 6.33 & \multirow{3}{*}{733} \\
\hline & 0.75 & 609 & \\
\hline & 1.0 & 733 & \\
\hline \multirow{3}{*}{ IV } & 0.5 & 4.77 & \multirow{3}{*}{163} \\
\hline & 0.75 & 7.53 & \\
\hline & 1.0 & 163 & \\
\hline \multirow{3}{*}{ V } & 0.5 & 492 & \multirow{3}{*}{778} \\
\hline & 0.75 & 778 & \\
\hline & 1.0 & 248 & \\
\hline \multirow{3}{*}{ VI } & 0.5 & 1050 & \multirow{3}{*}{1050} \\
\hline & 0.75 & 193 & \\
\hline & 1.0 & -- & \\
\hline \multirow{3}{*}{ VII } & 0.5 & 524 & \multirow{3}{*}{524} \\
\hline & 0.75 & 196 & \\
\hline & 1.0 & 192 & \\
\hline \multirow{3}{*}{ VIII } & 0.5 & 5.98 & \multirow{3}{*}{104} \\
\hline & 0.75 & 8.78 & \\
\hline & 1.0 & 104 & \\
\hline \multirow{3}{*}{ IX } & 0.5 & 244 & \multirow{3}{*}{475} \\
\hline & 0.75 & 475 & \\
\hline & 1.0 & 133 & \\
\hline
\end{tabular}




\section{Experimental work and flow visualization}

In order to visualize the flow field by smoke it is necessary to generate smoke. The use of smoke in wind tunnels began towards the end of the nineteenth century and has subsequently been developed into an important research tool. The principle of flow visualization in the present work is based on the injection of smoke in the flow field and taking pictures of the flow pattern. The smoke particles follow the path of airflow. The smoke being visible, the flow pattern is visible to the naked eye and can be photographed. The dispersion of smoke particles by the airflow is captured by a still camera. Visualizing the flow in the acrylic glass is complicated, because there are many different reflections that interrupts the image and makes it nearly impossible to recognize the flow. Smoke visualization is the most widely used method for natural convection flow visualization.

Experimental measurements have been carried out under steady-state conditions by stabilizing the room (thermal and fluid conditions) for more than 3 hours before recording air velocity, air temperature and visualizing smoke concentration. The function of the illumination system is to provide a uniform source of high intensity light which is dispersed by smoke particles so as to take their photographs. An interesting features (as shown in fig.11) have been observed when the smoke particle produce from incandescent stick enters in the room along with air smoke, it clearly shows the path of main stream two re-circulating cell have been clearly captured one near the ceiling and one near the floor.

\section{Validation}

The geometrical structure of the model room for the purpose of this investigation has width, depth and height of the room as $1.2 \mathrm{~m}, 0.6 \mathrm{~m}$ and $0.8 \mathrm{~m}$ respectively. In order to ensure the required unidirectional airflow at the inlet of the model room, a duct is fabricated. Air is allowed to enter the model room through one inlet vent through duct and leave through the other opposite outlet vent. For velocity measurement during experimentation using a thermal anemometer, a slot of $100 \mathrm{~cm} \mathrm{x} 3 \mathrm{~cm}$ is created at the top and bottom of the model to fit the strip of same dimension with holes of $6 \mathrm{~mm}$ at every $15 \mathrm{~cm}$. During measurement of velocity using thermal anemometer as shown in fig. 12, by inserting sensor probe through a hole, other holes are closed by a tape to ensure no undesirable air leakage. A calibrated anemometer was taken for conducting the experiments with an uncertainty of \pm 0.001 . The readings have been taken after five (5) consecutive trails. The simulated air velocities along the two horizontal inlet and outlet lines (line $1 \&$ line 2) in fig. 13 have been validated against the measured results. Line1 passes through the center of inlet and extends straight (parallel to the floor) to the opposite wall. Line 2 passes through the center of outlet and extends straight to opposite wall. The simulated air velocities along the two horizontal inlet and outlet center line (line $1 \&$ line 2) using $k-\varepsilon$ turbulence models (standard, RNG and Realization) have been validated against the measured results. Good agreement has been found between predictions using standard $k-\varepsilon$ turbulence model and experimental measurements as shown in fig. 14 (a) and (b).

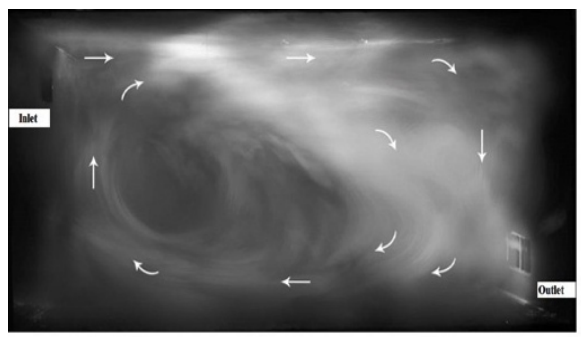

(a) Airflow pattern by visualization $(0.5 \mathrm{~m} / \mathrm{s})$ using smoke

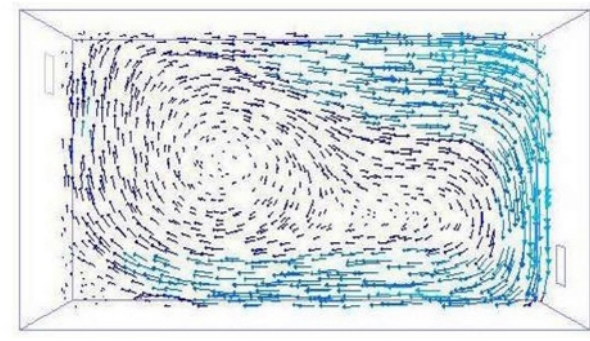

(b) Velocity vector by simulation

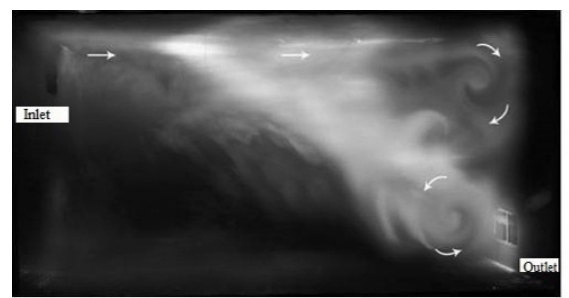

(c) Airflow pattern after stability $(0.5 \mathrm{~m} / \mathrm{s})$ using smoke

Figure 11. Comparison of air flow pattern using smoke with (a) $t=25 s$; (b) simulation; (c) $t=300 \mathrm{~s}$ 
Journal of Thermal Engineering, Research Article, Vol. 6, No. 5, pp.736-750, October, 2020

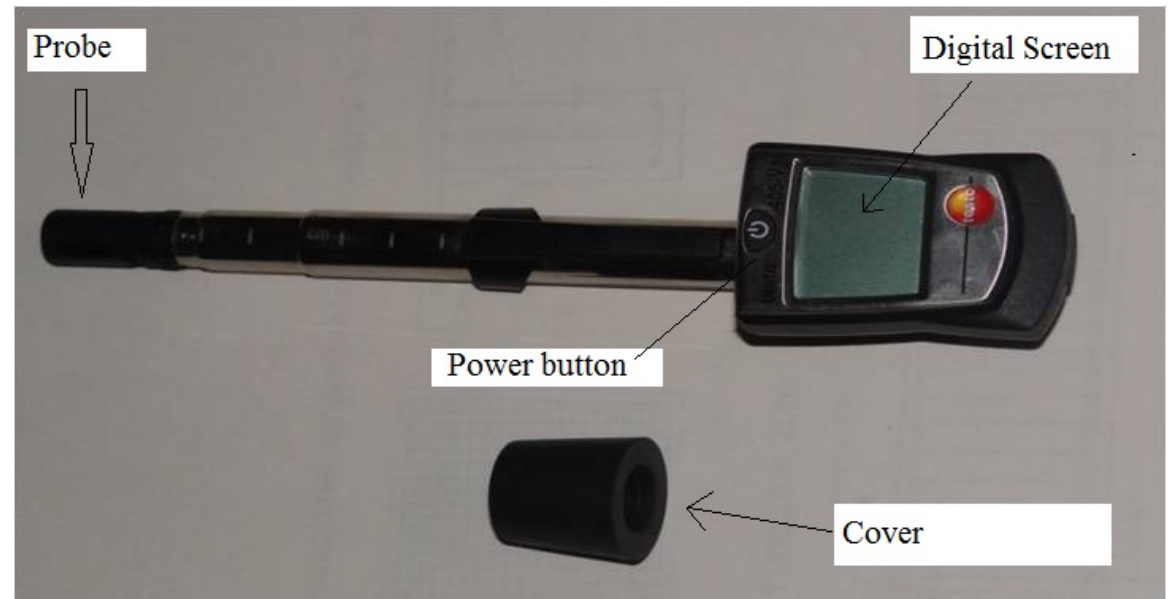

Figure 12. Thermal anemometer

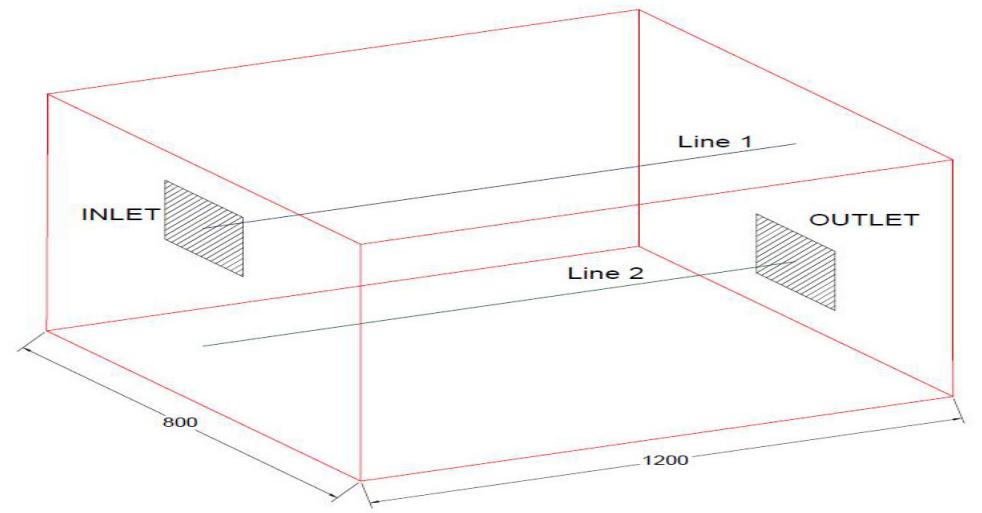

Figure 13. Locations for velocity measurement

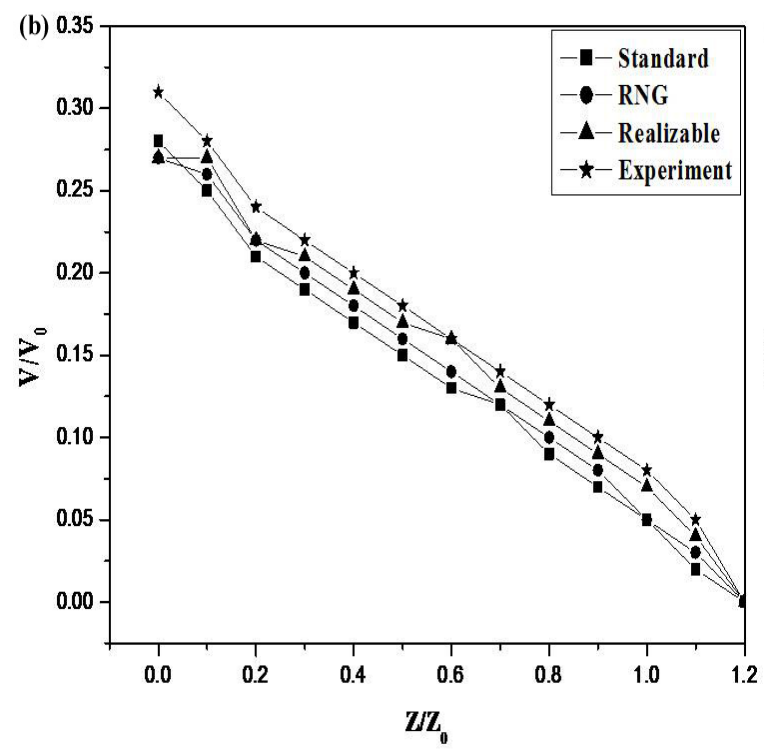

(a)

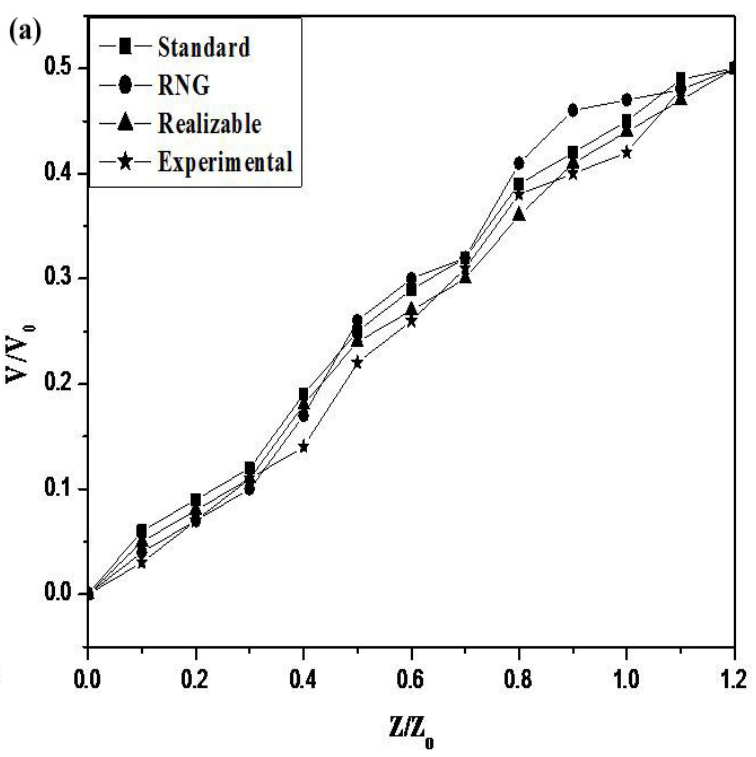

(b)

Figure 14. Locations for velocity measurement (a), Velocity along line 1 and (b) Velocity along line 2 


\section{CONCLUSION}

In the present work, the authors have taken into account twenty-seven (27) conditions of ICU for a government hospital at Raipur $\left(21.2514^{\circ} \mathrm{N}, 81.6296^{\circ} \mathrm{E}, 298 \mathrm{~m}\right.$ altitude above sea level), C.G., India region. The work is performed both numerically and experimentally to validate the results. In a case [Case-VI: (c)], it was observed by the researchers that the contaminant particle got settled in the ICU itself and thus they are highly hazardous to the health of the patient, doctor/nurse and other people on the ICU.

- The path of the main stream, as seen by smoke visualization technique, matches with the computed results.

- The CFD predictions using the standard $k-\varepsilon$ turbulence model have resulted in good correlations with the air velocity measurements as well as smoke visualization.

- The ventilation in case-VI was found to take more time in leaving the contaminant from the ICU, as compared to other cases.

- Cases II, IV and VIII were found to be optimal for the contaminant to leave from the ICU.

In this study, it can observe that the nanoparticles play a significant role in the UV-Vis wavelength ranges where a large amount of the solar energy is dissipated. The extinction coefficient of the media is enhanced and affects the radiation transfer performance. Particle size and number have important effects on the thermal radiation transfer, increasing particle concentration leads to enhance the radiative properties.

\section{NOMENCLATURE}

$\mathrm{ACH}$

CFD

$\mathrm{C}_{1}, \mathrm{C}_{2}, \mathrm{C}_{3}, \mathrm{C}_{\mu}$

$\mathrm{C}_{\mathrm{d}}$

$d_{p}$

E, W, N, S, C

$F_{x}$

$\mathrm{f}_{\mu}, \mathrm{f}_{1}, \mathrm{f}_{2}$

$\mathrm{g}$

$\mathrm{G}_{\mathrm{k}}$

$\mathrm{G} b$

$\mathrm{HCW}$

ICU

$\mathrm{K}$

$\mathrm{P}$

$\operatorname{Re}$

$\mathrm{S}$

SR

$\mathrm{S}_{\phi}$

$\mathrm{t}$

$\mathrm{T}$

$\mathrm{u}$

V

W

$\mathrm{y}^{+}$

Z

Subscripts

o

W

$-$

$*$

Greek symbol

$\alpha$
Air change per hour $\left(\mathrm{h}^{-1}\right)$

Computational fluid dynamics

Empirical constants in turbulence model

Drag coefficient $(\mathrm{N})$

Particle diameter (m)

East, West, North, South, Ceiling

Additional force exerted on the particles (N)

Model functions

Gravity $\left(\mathrm{m} / \mathrm{s}^{2}\right)$

Generation of turbulent kinetic energy

Generation of turbulent kinetic energy due to buoyancy

Health care worker

Intensive care unit

Turbulence kinetic energy $\left(\mathrm{m}^{2} / \mathrm{s}^{2}\right)$

Pressure $\left(\mathrm{N} / \mathrm{m}^{2}\right)$

Reynolds number

Standard deviation of the particle (fluctuating velocity)

Supply air flow $\left(\mathrm{m}^{3} / \mathrm{s}\right)$

Source term in governing equation

Time (seconds)

Temperature $\left({ }^{\circ} \mathrm{C}\right)$

Velocity (x-direction) $(\mathrm{m} / \mathrm{s})$

Velocity (y-direction) $(\mathrm{m} / \mathrm{s})$

Width (m)

Characteristics y distance from the nearest wall surface

Ratio between the particle mass flow rate and gases mass flow rate

Inlet

Wall

Time average value

Non dimensional value

Thermal diffusivity 
Journal of Thermal Engineering, Research Article, Vol. 6, No. 5, pp.736-750, October, 2020

$\beta$

$\Gamma \phi$

$\Delta$

$\mu$

$\mu \mathrm{t}$

$\rho$

$v$

$\varepsilon$

$\sigma \mathrm{k}, \sigma \varepsilon$

$\phi$

$\tau \omega$

Coefficient of thermal expansion

Effective diffusivity

Difference

Dynamic viscosity

Turbulent viscosity

Mass density

Kinematic viscosity

Turbulent kinetic energy dissipation rate $\left(\mathrm{m}^{2} / \mathrm{s}^{3}\right)$

Turbulent Prandtl numbers for turbulent kinetic energy and energy dissipation rate

General dependent variable

Shear stress at the wall

\section{REFERENCES}

[1] Runchal AK. Brian spalding: CFD \& reality: A personal recollection. J Franklin Inst. 2014; 351(1):65-87. https://doi.org/10.1016/j.jfranklin.2012.12.004

[2] Sun Z, Wang S. A CFD-based test method for control of indoor environment and space ventilation. Build Environ. 2010;45(6):1441-1447. https://doi.org/10.1016/j.buildenv.2009.12.007

[3] Villafruela JM, Olmedo I, Ruiz de Adana M, Méndez C, Nielsen P V. CFD analysis of the human exhalation flow using different boundary conditions and ventilation strategies. Build Environ. 2013;62:191-200. https://doi.org/10.1016/j.buildenv.2013.01.022

[4] Marocco L, Mora A. CFD modeling of the Dry-Sorbent-Injection process for flue gas desulfurization using hydrated lime. Sep Purif Technol. 2013;108:205-214. https://doi.org/10.1016/j.seppur.2013.02.012

[5] Zhang Z, Chen Q. Comparison of the Eulerian and Lagrangian methods for predicting particle transport in enclosed spaces. Atmos Environ. 2007;41(25):5236-5248. https://doi.org/10.1016/j.atmosenv.2006.05.086

[6] Yau YH, Chandrasegaran D, Badarudin A. The ventilation of multiple-bed hospital wards in the tropics: A review. Build Environ. 2011; 46(5):1125-1132. https://doi.org/10.1016/j.buildenv.2010.11.013

[7] Balocco C, Lio P. Assessing ventilation system performance in isolation rooms. Energy Build. 2011; 43(1):246-252. https://doi.org/10.1016/j.enbuild.2010.09.020

[8] Lim T, Cho J, Kim BS. The predictions of infection risk of indoor airborne transmission of diseases in highrise hospitals: Tracer gas simulation. Energy Build. 2010; 42(8):1172-1181. https://doi.org/10.1016/j.enbuild.2010.02.008

[9] Verma T N, Sinha S L. Numerical Simulation of Contaminant Control in Multi-Patient Intensive Care Unit of Hospital Using Computational Fluid Dynamics. J. Med. Imaging and Health Info. 2015; 5:1088-1092. https://doi.org/10.1166/jmihi.2015.1500

[10] Verma T N, Sinha S L. Contaminant control in Intensive Care Unit of Hospital. Appl. Mechanics and Materials. 2014; 592-594. https://doi.org/10.4028/www.scientific.net/AMM.592-594.2486

[11] Kalliomäki P, Saarinen P, Tang JW, Koskela H. Airflow patterns through single hinged and sliding doors in hospital isolation rooms - Effect of ventilation, flow differential and passage. Build Environ. 2016; 107:154168. https://doi.org/10.1016/j.buildenv.2016.07.009

[12] Qian H, Li Y, Seto WH, Ching P, Ching WH, Sun HQ. Natural ventilation for reducing airborne infection in hospitals. Build Environ. 2010; 45(3):559-565. https://doi.org/10.1016/j.buildenv.2009.07.011

[13] Kwon S-B, Park J, Jang J, et al. Study on the initial velocity distribution of exhaled air from coughing and speaking. Chemosphere. 2012; 87(11):1260-1264. https://doi.org/10.1016/j.chemosphere.2012.01.032

[14] Hang J, Li Y, Jin R. The influence of human walking on the flow and airborne transmission in a six-bed isolation room: Tracer gas simulation. Build Environ. 2014; 77:119-134. https://doi.org/10.1016/j.buildenv.2014.03.029

[15] Ma X, Shao X, Li X, Lin Y. An analytical expression for transient distribution of passive contaminant under steady flow field. Build Environ. 2012; 52:98-106. https://doi.org/10.1016/j.buildenv.2011.12.013

[16] Noh K-C, Kim H-S, Oh M-D. Study on contamination control in a minienvironment inside clean room for yield enhancement based on particle concentration measurement and airflow CFD simulation. Build Environ. 2010; 45(4):825-831. https://doi.org/10.1016/j.buildenv.2009.09.001

[17] Yam R, Yuen PL, Yung R, Choy T. Rethinking hospital general ward ventilation design using computational fluid dynamics. J. Hospital Infection. 2011; 77: 31-36. https://doi.org/10.1016/j.jhin.2010.08.010

[18] Tripathi B, Moulic SG. Investigation of Air Drafting Pattern Obtained from the Variation in Outlet Positions inside a Closed Area. J. Applied Fluid Mechanics. 2012; 5 (4). https://doi.org/10.36884/jafm.5.04.19455 
[19] Martinho N, Lopes A, Gameiro da Silva M. Evaluation of errors on the CFD computation of air flow and heat transfer around the human body. Build Environ. 2012;58:58-69.

https://doi.org/10.1016/j.buildenv.2012.06.018

[20] Gupta JK, Lin CH, Chen Q. Characterizing Exhaust Airflow from Breathtaking and Talking. Indoor Air. 2010; 20: 31-39. https://doi.org/10.1111/j.1600-0668.2009.00623.x

[21] Sinha SL, Arora RC, Roy S. Numerical simulation of two-dimensional room air flow with and without buoyancy. Energy Build. 2000;32(1):121-129. https://doi.org/10.1016/S0378-7788(99)00047-X

[22] Villafruela JM, San José JF, Castro F, Zarzuelo A. Airflow patterns through a sliding door during opening and foot traffic in operating rooms. Build Environ. 2016;109:190-198. https://doi.org/10.1016/j.buildenv.2016.09.025

[23] Chao CYH, Wan MP, Morawska L, et al. Characterization of expiration air jets and droplet size distributions immediately at the mouth opening. J Aerosol Sci. 2009;40(2):122-133. https://doi.org/10.1016/j.jaerosci.2008.10.003

[24] Cheong KWD, Djunaedy E, Poh TK, et al. Measurements and computations of contaminant's distribution in an office environment. Build Environ. 2003; 38(1):135-145. https://doi.org/10.1016/S0360-1323(02)000318

[25] King M-F, Noakes CJ, Sleigh PA, Camargo-Valero MA. Bioaerosol deposition in single and two-bed hospital rooms: A numerical and experimental study. Build Environ. 2013; 59:436-447. https://doi.org/10.1016/j.buildenv.2012.09.011

[26] Indian Society of Heating, Refrigerating and Air-Conditioning Engineers Inc. Handbook e HVAC applications 2007.

[27] Morsi S A, Alexander A J. An investigation of particle trajectories in two-phase flow systems. Journal of Fluid Mech 1972, 55:193-208. https://doi.org/10.1017/S0022112072001806

[28] Crowe C T, Sommerfeld M, Tsuji T. Multiphase flow with droplet and particles. Boca Roton: CRC Press 1998.

[29] Launder B E, Spalding D B. The numerical computation of turbulent flows. Computer method in Applied Mechanics and Engineering 1974, 3: 269-289.

[30] Verma TN, Nashine P, Singh DV, Singh TS, Panwar D. ANN: Prediction of an experimental heat transfer analysis of concentric tube heat exchanger with corrugated inner tubes. Applied Thermal Engineering 2017;120: 219-227. https://doi.org/10.1016/j.applthermaleng.2017.03.126

[31] Verma TN, Sahu AK, Sinha SL. Study of particle dispersion on one bed hospital using Computational Fluid Dynamics; Materials Today: Proceedings, Elsevier 2017; 4(9): 10074-10079.

https://doi.org/10.1016/j.matpr.2017.06.323

[32] Verma TN, Sinha SL. Contaminant control in intensive care unit (ICU) using CFD modeling; International Journal of Mechanical and Industrial Engineering (IJMIE) 2013; 3(1).

[33] Verma TN, Sinha SL. Trajectory of contaminated particle in intensive (ICU) of hospitals using numerical modeling; International Journal on Design \& Manufacturing Technologies (IJDMT) 2015; 9(1): 43-47.

[34] Verma TN, Sahu AK, Sinha SL. Numerical Simulation of Air Pollution Control in Hospital. In: Sharma N., Agarwal A., Eastwood P., Gupta T., Singh A. (eds) Air Pollution and Control. Energy, Environment, and Sustainability. Springer, Singapore 2018. https://doi.org/10.1007/978-981-10-7185-0_11

[35] Sahu AK, Verma TN, Sinha SL. Numerical simulation of air flow to ventilate intensive care unit of hospital; International Research Publication House; Computer Application in Education and Research for Science and Technology 2018; 1: 131-138.

[36] Gorji MH, Gorji TB, Bandpy MG. Details of regional particle deposition and air flow structures in a realistic model of human tracheobronchial airways: two-phase flow simulation; Computers in Biology and Medicine 2016; 71: 1-17. https://doi.org/10.1016/j.compbiomed.2016.04.017

[37] Gorji MH, Ghajar M. Modeling of the air conditions effects on the power and fuel consumption of the SI engine using neural networks and regression. J Braz. Soc. Mech. Sci. Eng. 2017; 39:375-384. https://doi.org/10.1007/s40430-016-0539-1

[38] Pourmehran O, Gorji MH, Bandpy MG, Baou M. Comparison between the volumetric flow rate and pressure distribution for different kinds of sliding thrust bearing. Propulsion and Power research 2015; 4(2): 84-90.

https://doi.org/10.1016/j.jppr.2015.05.002

[39] Ahmed N, Shah NA, Ahmad B, Shah SIA, Ulhaq S, Gorj MR. Transient MHD convective flow of fractional nanofluid between vertical plate. Journal of Applied and computational Mechanics. https://doi.org/10.22055/JACM.2018.26947.1364 
[40] Ünlügençoğlu K, Yurtseven A, Alarçin F. Shipping emission dispersions of the port of ambarli via CFD modelling. Journal of Thermal Engineering. 2020; 6 (2):1-14. https://doi.org/10.18186/thermal.713553

[41] Prakash O, Arora R. Flow Characterization of multi-phase particle slurry in thermal power plants using computational fluid dynamics. Journal of Thermal Engineering. 2020; 6 (1):187-203. https://doi.org/10.18186/thermal.672785

[42] Sener R, Ozdemir MR, Yangaz MU. Effect of the geometrical parameters in a domestic burner with crescent flame channels for an optimal temperature distribution and thermal efficiency. Journal of Thermal Engineering. 2019; 5 (6):171-183. https://doi.org/10.18186/thermal.654303

[43] Netam N, Sanyal S, Bhowmick S. Assessing the impact of passive cooling on thermal comfort in LIG house using CFD. Journal of Thermal Engineering. 2019; 5 (5):414-421. https://doi.org/10.18186/thermal.623212

[44] Acikgoz O. Determination of convective, radiative, and total heat transfer characteristics over a radiant heated ceiling: A computational approach. Journal of Thermal Engineering. 2019; 5 (5):372-384. https://doi.org/10.18186/thermal.623191

[45] Ghogare AG, Sinha SL, Verma TN. Numerical simulation for optimization of the indoor environment of an occupied office building using double-panel and ventilation radiator; Journal of Building Engineering 2020; 29 (101139): 1-22. https://doi.org/10.1016/j.jobe.2019.101139

[46] Anthony AS, Verma TN. Numerical analysis of natural convection in a room heated with a radiator and its implication on thermal comfort; Journal of Thermal Engineering. (Accepted).

[47] Sahu AK, Verma TN, Sinha SL. Numerical Simulation of Air Flow in Multiple beds Intensive Care Unit of Hospital; International Journal of Automotive and Mechanical Engineering (IJAME) 2019; 16,(2): 67966807. https://doi.org/10.15282/ijame.16.2.2019.24.0511

[48] Ghogare AG, Sinha SL, Verma TN. Effect of inlet airflow direction on the indoor environment of a naturally ventilated room using CFD; International Journal of Engineering and Advanced Technology (IJEAT) 2020; 9 (3): 580-591.

[49] Arvind Kumar Sahu, Sinha SL, Verma TN. Numerical simulation of air flow to ventilate intensive care unit of hospital; Computer Application in Education and Research for Science and Technology; International Research Publication House (IRPH) 2018; 131-138.

[50] Bayareh M, Nouurbakhsh A. Study on the effect of porous plates on the tank bottom on the boiling process. Journal of Thermal Engineering. 2019; 5 (3):149-156. https://doi.org/10.18186/thermal.540120

[51] Kaya H, Ekiciler R, Arslan K. CFD analysis on laminar forced convective heat transfer for TiO2/water nanofluid in a semi-circular cross-sectioned micro-channel. Journal of Thermal Engineering. 2019; 5 (3):123137. https://doi.org/10.18186/thermal.540043

[52] Menni Y, Azzi A, Zidani C. CFD simulations of thermo-aeraulic fields in a channel with multiple baffle plates. Journal of Thermal Engineering. 2018; 4 (6):2481-2495. https://doi.org/10.18186/thermal.465696

[53] Gul MZ, Koten H, Yilmaz M, Savci IH. Advanced numerical and experimental studies on CI engine emissions. Journal of Thermal Engineering. 2018; 4 (4):2234-2247. https://doi.org/10.18186/journal-ofthermal-engineering.434044

[54] Koten H. Performance analysis of a diesel engine with multi-dimensional framework. Journal of Thermal Engineering. 2018; 4 (4):2201-2210. https://doi.org/10.18186/journal-of-thermal-engineering.414153 